\title{
PROFESSIONAL ACTIVITY IN THE CONTEXT OF HEALTH EDUCATION: A SYSTEMATIC REVIEW
}

\author{
Italla Maria Pinheiro Bezerra ${ }^{1,2}$, Maria de Fátima Antero Sousa Machado ${ }^{3}$, \\ Orivaldo Florencio de Souza ${ }^{5}$, Jennifer Yohanna Ferreira de Lima Antão ${ }^{4}$, \\ Maria Natália Leite Dantas ${ }^{4}$, Alberto Olavo Advincula Reis ${ }^{1}$, Ana Aline Andrade Martins ${ }^{4}$, \\ Luiz Carlos de Abreu ${ }^{1}$
}

\begin{abstract}
Describe educational practices performed by health professionals with reference to the paradigm of health promotion. It is systematic review the search for articles in databases: Medline, Lilacs and SciELO, published during the period from 2003 to 2013. The search was performed using the integrated method, using the terms: health promotion, health education and experiences. Given the results, was possible to demonstrate the importance of conducting health education experiences in different contexts: primary care, hospitals and schools with various themes and methodologies adopted. However, although these experiences implemented primarily with a view to promoting health, highlighting elements such as autonomy, empowerment and decision-making, it was found that even if educational actions on normative health are carried out they weaken the process of the empowerment of the individuals involved.
\end{abstract}

Key words: Health promotion, health education, experiences.

\section{INTRODUCTION}

The educational activities undertaken in the health field for many decades have been characterized as normative procedures, of hygienic discourse within the perspective of the control and prevention of diseases ${ }^{1,2}$.

It may, however, be said that the concepts and objectives of health education have been adapted in accordance with the changes in the paradigm that have come about in the health sector, in response to the notable medicalization of health ${ }^{3}$.

Thus it is that one understands that an element that came to reinforce these changes were the discussions on health promotion, with special emphasis on the Lalonde Report of 1976, as this is seen as an initial landmark of modern health promotion in Canada. This report made it evident that the traditional assistencialist pattern was inefficient and stated that health is determined by a set of factors which may be grouped under four headings: Human biology, Environment, Life styles and the Organization of health attention ${ }^{4}$.

Another landmark which contributed to the consolidation of the concept of health promotion occurred as from the 1st International Health Promotion Congress, which concluded with the Letter from Ottawa and initiated a movement in Canada since known as Health Promotion ${ }^{5}$.

After these movements health promotion came to be defined as the "process of the enabling of the community to act in the improvement of its quality of life and health, including a greater participation in the control of this process"

Thus, within the process of health promotion, educational actions should be developed and implemented in such a way as to be coherent with the promotion of the health of individuals, seeing that this latter should present itself as an instrument capable of stimulating the empowerment of the individuals involved in the activities 7,8 .

Within this perspective, on the Brazilian scene there arose a new public assistance model after the Health Reform movement which led, as a major conquest, to the creation of a health system named the Unified Health System - SUS, governed by the principles of universality, integrality and equity ${ }^{9}$

The same has been consolidated as a public assistence model as from the implantation of the Family Health Strategy (Estratégia de Saúde da Família- ESF) ${ }^{10,11}$.

The assistance implemented by the ESF diverges from the traditional model as it proposes changes in the conception of the health-disease process, and invests, also, in health promotion actions which relate health to living conditions and quality of life ${ }^{12}$.

Thus it is understood that actions in health education, so important in the construction of the ideas of care and integrality are believed to be relevant to the undertaking of a study which may express the organization and characterization of

1 Laboratório de Delineamento e Escrita Científica. Departamento de Ciências Básicas, Faculdade de Medicina do ABC, Av. Príncipe de Gales, 821, 09060-650. Santo André, SP, Brazil.

2 Docente da Faculdade de Juazeiro do Norte- FJN e da Universidade Regional do Cariri-URCA.

3 Doutora em Enfermagem. Juazeiro do Norte- Ceará, Brazil.

4 Especialista em Saúde da Família. Juazeiro do Norte-Ceará, Brazil.

Corresponding author: nuep@fjn.edu.br

Suggested citation: Bezerra IMP, et al. Professional activity in the context of health education: a systematic review. 24(3): 255-262 Manuscript submitted Feb 05 2014, accepted for publication Oct 212014. 
these educational actions arising from scientific production.

The objective is thus to analyze the educational practices conducted by professionals on the basis of the health promotion paradigm.

\section{METHODS}

This is a systematic survey carried out in the following stages: establishment of the hypothesis and the objectives of the survey; establishment of the criteria for the inclusion and exclusion of articles (selection of sample); definition of the information to be culled from the articles selected, analysis of the results, discussion and presentation of the results and the publication of the survey.

The following question was formulated to guide the survey: Do the educational practices carried out by the professionals concerned adopt distinct forms of organization and are they consistent with the presuppositions of health promotion?

For the selection of the articles to be analyzed a search was undertaken in the databases: Medline, Lilacs and the Scientific Electronic Library - SciELo for articles published during the period 2003 to 2013, inclusive. The search was undertaken by means of the integrated method, using the terms: health promotion, health education and experiences.

The inclusion criteria defined for this present survey were that the studies should: deal with experiences of educational practice, be articles, and have been published in Portuguese, English or Spanish. Thus doctoral theses, masters' dissertations and letters to the reader were excluded from this survey.

As may be seen in figure 01,117 articles were found which addressed health education, though after an exhaustive examination of the same on the basis of a questionnaire for the identification of educational experiences, only articles which assessed some experience in health education undertaken in health service units were selected, thus giving a total of 23 studies, whether national or foreign. See figure 01.

Figure 1: Selection of the research articles on the databases

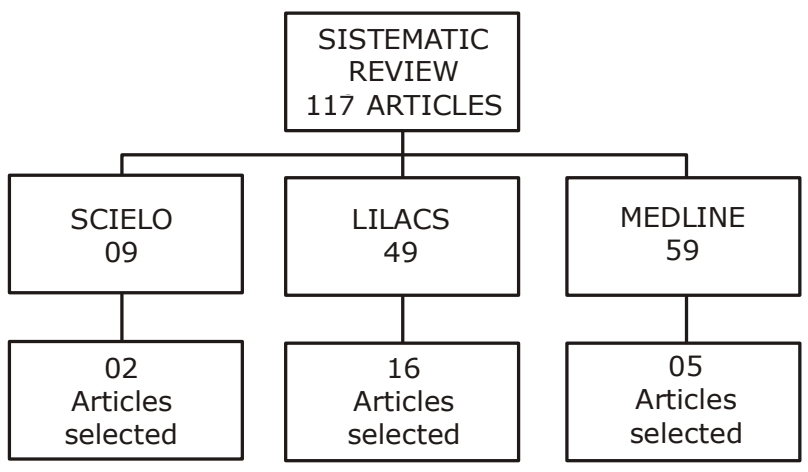

The articles were then organized in tables which illustrate the characterization of the articles as to type, year of publication and methodological approach adopted, as also the organization of those actions and the evidence of the results obtained.

\section{RESULTS}

The distribution of the manuscripts is set out in table form, as described below: table 1 classifies the articles by type of publication and description of the contents; table 2 gives a characterization of the health education actions described and table 3 , a synthesis of the results obtained, giving the perceived evidence on the basis of the experiences studied.

Table 1: Characterization of the articles by type of publication and delineation of the studies. Period 2003-2013

$\begin{array}{lccc}\text { TYPES OF PUBLICATION } & \text { LILACS } & \text { SCIELO } & \text { PUBMED } \\ \text { Original article } & 07 & 02 & 04 \\ \text { Report of experience } & 08 & 00 & 00 \\ \text { Others } & 01 & 00 & 01 \\ \text { TOTAL } & \mathbf{1 6} & \mathbf{0 2} & \mathbf{0 5} \\ \text { TYPES OF STUDY } & \text { LILACS } & \mathbf{S C I E L O} & \mathbf{P B M E D} \\ \text { Research-action } & 01 & 01 & 01 \\ \text { Intervention } & 06 & 00 & 00 \\ \text { Life History } & 01 & 00 & 01 \\ \text { Descritiptive } & 08 & 01 & 04 \\ \text { TOTAL } & \mathbf{1 6} & \mathbf{0 2} & \mathbf{0 5}\end{array}$

Scielo: Scientific Eletronic Library Online

Lilacs: Literatura Latino-Americana e do Caribe em Ciências da Saúde

Pubmed: Public/Publish Medline 
Table 2: Organizations of actions in Health Education. Períod 2003-2013

\section{Scenarios}

Primary Care

School

Hospital

TOTAL

Themes addressed

Action of the health of the family nurse/team

Chronic diseases

Health of the elderly

Sexual/reproductive health

Feeding education/breast-feeding

Child/adolescent health

Oral health

TOTAL

\section{Methodologies employed}

Individual guidance

Conversation circles

Physical activity

Educational games

Theater

Groups for talks

Focal groups

Workshops

Miscellaneous

TOTAL

\section{Quantity}

16

04

03

23

Quantity

03

06

02

05

03

03

01

23

Quantity

01

06

01

02

02

08

01

01

02

23

Table 3: Synthesis of the manuscripts relating to the experiences of health education practice. Period 2003-2013

\section{Leitåo AM. et al $(2004)^{23}$}

Motta MDAGC. et al $(2004)^{28}$

Ramfelt E. Lützén $\mathrm{K}$ $(2005)^{27}$

Torres HC. Hortale V.A. Schall. V (2006) ${ }^{31}$

Girondi JBR, Nothaft SCS, Mallmann FMB $(2006)^{17}$

Pereira JM, Frazão HL $(2006)^{32}$

Silva MDAA. et al $(2006)^{15}$

Moncunill IA. et al $(2007)^{33}$

Penteado RZ. et al $(2007)^{34}$
The need to intensify ever earlier family-health education was verified; advising them, for example, to avoid the use of industrialized foodstuffs; to give closer attention to the health professionals who work with children, and to the benefits of a healthy infancy's benefiting the life quality of the future adult directly.

Indicate the importance of implementing family health education programs, offering information enabling parents to face the experience of early motherhood seeking to reduce the factors of biological, environmental, behavioral. socioeconomic and cultural risk for the adolescent and her baby.

The participation of the patient in the treatment and in the taking of decisions regarding care is understood as the health promotion approach to dealing with disease.

Made the construction of knowledge on the part of the participants and the exchange of experiences between the same possible, as well as the understanding of the individual experience of disease on the part of the health professional.

The problematic experiences encountered in working with adolescents led to the promotion of important changes in pedagogical conceptions and relationships, with a view to the transformation of the situation by the subject, who thus exercises citizenship.

Permitted the recognition of the complexity of the aspects involved in the process of reorientation with a view to changing eating habits and promoting a healthier lifestyle, as well as of the importance of working together with the multiprofessional health team and the users.

The holding of groups is being consolidated as an assistential-style clinical strategy, while the educative-participative dimension and the empowerment of patients and of the community for the exercise of citizenship are seen to be reduced.

Games as mediators of oral health content provided with a tool adequate for children and adolescents succeed in consolidating healthy behaviors, because their design respects the diagnosis of their potential.

The themes were guided by a broad and affirmative vision of health, contemplating aspects of prevention and health promotion. The actions were coherent with a conception of active subject and multiplying agent, within the perspective of health promotion in the school community. 
Table 3: Synthesis of the manuscripts relating to the experiences of health education practice. Period 2003-2013

\author{
Costa SM, Barbosa \\ AAA, Brito EWG \\ $(2008)^{35}$ \\ Meneghel SN. et \\ al $(2008)^{22}$ \\ Rêgo MAB (2008) ${ }^{24}$ \\ Barbosa LDE A. et al \\ $(2009)^{36}$
}

Horta NDE C (2009) ${ }^{25}$

Carneiro DGDEB. et al $(2010)^{37}$

Combinato DS. et al $(2010)^{38}$

Firmino R. et al $(2010)^{26}$

Diaz CMG. et al $(2010)^{14}$

Roecker S, Marcon SS $(2011)^{42}$

Truesdale-Kennedy $M$, Taggart L, Mcilfatrick S $(2011)^{20}$

Baldissera VDA, Bueno SMV $(2012)^{39}$

Baldissera VD, Bueno SM,Hoga LA (2012) 40

Rossman $\mathrm{CL}$, Ayoola $\mathrm{AB}(2012)^{41}$
Personal and collective processes and experiences, seen within a broad field of corporeity, transcendence and subjectivity, which show a change of behavior and the adoption of healthy habits.

The experiences of story-teller workshops understanding that the intervention which we create collectively indicate paths of change, resignification and resistance.

Dialogue-style educational activity was capable of contributing to the awakening of the reflective, critical and creative potential of the group, and is thus presented as an intervention strategy for the nurse who works with a view to the emancipation of his clients.

The population proved responsive to the actions undertaken, thus the educational process developed was successful using a subject-subject - non-vertical - approach in the quest for community empowerment relating to the questions addressed, emphasizing the importance of a continuing process of health education.

One perceives the reflex of the co-existence of the assistential models of health, the difficulties of breaking with the medical-centred and curativist practice and the incorporation of the health referencials which have as their pillar the organized offer of actions which spring from the real situation and health needs of the user.

Show the need for educational actions which contribute to clarification and followup in Family Health, in a process of dialog which involves health professionals and the organized community.

Group activities constitute a privileged space for the constitution of support networks, the establishment and intensification of affective links; the reflection and awareness of the determinations of the health-disease process; organization and mobilization for effective social control; as well as being a space for teachinglearning, guidance, intervention and health education.

Educational groups constitute a strategy effectively capable of reorienting the health care of the elderly within the health promotion perspective of Primary Care.

Group activities give the opportunity of clarifying doubts and health education on the health-disease process, thus making of them an instrument of health promotion and provider of autonomy in relation to self-care.

On the individual level are noted guidance in child education, while on the collective level group educational activities were more frequent: pregnant women, hypertensives and smokers. The assessment of the educational needs of the population was made without the community's effective participation.

Stresses the need for accessible information to facilitate health promotion and health education among women with intellectual deficiency, for the providers of care and health professionals, with a view to improving knowledge and awareness of breast cancer.

Recognition of the value of: the group's prior knowledge, shared and carefully defined educational planning, the links established and the consequent reinforcement of human abilities for creativity and the solution of problems were results unmeasurable but observable in educational practice and coherent with freirean pedagogy.

The educational dialog, participatory and continuous approaches of observationparticipation are strategies adopted in support of the care of women and their educational needs in the attempt to improve the expression of the sexuality of elderly women.

The ability of nursing to implement educational actions for women in the pre-natal and post-natal phases can enable mothers to take decisions on effective and sustained breast-feeding.

\section{DISCUSSION}

In the light of the transformation of the health paradigm, health education comes to acquire a new configuration, in the sense of corresponding to the principles underlying health promotion as regards the changes in behavior and the improvement in the health of the population ${ }^{3}$. Thus, changes are called for - extending from the organization of these practices to the health education model to be applied.
In the light of the above, it will be seen that the various scenarios in which health education is practiced are addressed in the articles evaluated. However, units of primary health care predominate as the preferred space for the implementation of the actions - which are rarely undertaken in other scenarios.

In this same line of enquiry, other research highlights the Family Health Strategy (the ESF) as a basic element in the practical application of health education in the light of the modifications made to 
conventional health care practices to create a work model focusing on prevention and the promotion of family health, guided by the principles of integrality and the hierarchical structuring of actions in health service units ${ }^{13}$

However, hospital institutions have also been the scene for the development of these educational actions, as a study has demonstrated. These argue that as one works on health education in a hospital unit, it becomes possible to develop a new view of care within the daily routine, as also to develop ideas and a team spirit to appreciate the knowledge of each person, giving due attention to his beliefs, culture, values, in defence of genuine care developed by an interdisciplinary team ${ }^{14}$.

We consider a change of paradigm to be possible as regards health promotion in the atmosphere of the hospital, where clinical practice and technique still predominate ${ }^{15}$ It is important to emphasize that the present needs of the individual require that a new vision, a new posture, another culture should be cultivated within hospitals with a view to working on health rather than disease.

However, even though health services are highly important in guaranteeing the attention of individuals and populations, the health conditions of the communities do not depend only on them. Many health promotion and protection actions are undertaken by organizations which do not belong to the sector. Thus, for example, the educational actions undertaken in schools are noteworthy and are considered to be fundamental for the promotion of health ${ }^{16}$.

Within this context, on approaching sexuality within the school scene it is evidently of great importance to create an atmosphere favorable to health promotion by means of health education, seeing that this would act as a meaningful social space whither the adolescent could take his experiences and expectations regarding life and express his curiosity as regards sexuality, among other aspects of health ${ }^{17}$.

Thus it is important to underline that it is not enough just to open a space for the promotion of health, it is, further, necessary that that space should permit the creation, in the users, of the awareness of their co-responsibility for these health promotion practices, in the mobilization, training and development in the apprenticeship of both individual and social abilities to deal with the healthdisease process ${ }^{18}$.

Noteworthy among the themes addressed within these different contexts, are the investigations into chronic diseases as well as the focus on sexual and reproductive health. These investigations sought to identify the relationship between the actions of health education and their influence on the promotion of the health of individuals. It is thus perceived that the ability of nursing to implement educational actions for women in the pre- and post-natal periods may train the mothers to take decisions to ensure efficacious and sustained breast-feeding ${ }^{19}$.

It has not yet been possible to establish the need to make information accessible for the purpose of promoting health promotion and education among women with some intellectual deficiency, or the carers or health professionals so as to perfect their knowledge and awareness regarding breast cancer ${ }^{20}$

Investigations inherent to sexual and reproductive health are justified as this is a broad field which constitutes one of the integrating themes within the group of the health promotion of the individual and the community, whereas, on the other hand, the addition of groups predisposed to sexual and reproductive risk is growing and calls for the intensification of health education actions within this context ${ }^{14}$.

However, whereas on one hand it is considered important to work on this theme among the elderly population, on the other, sexual and reproductive health is a theme which is frequently discussed with adolescents, when the subject is broached in the school context with this public ${ }^{17}$.

On another point, there are authors who highlight the fact that the Brazilian scene presents an increased proportion of women with AIDS, though the mortality rate among this population is smaller, which means that events related to the heterosexualization, femininization and interiorization of this disease draw attention to the need for action by means of the empowerment of the individuals concerned 22 .

Educational actions have also been carried out to attend to chronic diseases, a fact which may be justified by the increase in these diseases at the present time. When considering this reality, therefore, studies point to the existence of two therapeutical options made available to the public sector: those addressed to acute crises and the demand seeking to address chronic diseases ${ }^{21}$.

Thus in the articles assessed, when the follow-up of Systemic Arterial Hypertension - SAH in children in the context of the ESF was investigated, it was discovered that there is a need ever earlier to intensify education related to the health of families, advising them, for example, to avoid the use of manufactures foodstuffs; to pay more attention to the health professionals who work with children, and the benefits of a healthy childhood which directly influences the quality of life of the future adult ${ }^{23}$

Thus, in working with health education as an intervention strategy with sufferers of diabetes, authors concluded that educational activity as a nursing intervention strategy contributed to the awakening of the critical and creative reflection of the group, constituting an intervention strategy for the nurse who seeks the emancipation of his clients $^{24}$.

As regards the methodologies adopted for the implementation of the health education actions assessed, various of them were investigated including: educational groups, conversation groups, games, theater and workshops.

The use of the group as a strategy for the practice of health education emerges as an instrument which relates the various spheres of human life: the social sphere, seeing that it permits the approximation, growth and sharing of interests and expectations, builds up subjects who, in their 
turn, construct communities; and the biological, which abbreviates the various environmental, constitutional and genetic determinations, as well as expressing the personal attitude of each one, in the way in which he interacts with the internal, physical, psychic and external environment ${ }^{15}$.

In the study of the above-mentioned aspects, the educational actions of eight Family Health Units (FHU) located in Cuiabá-MT-Brazil, which took place by means of educational groups in which the professional nurse participated, were assessed ${ }^{15}$. The actions were undertaken in the form of group activities as health promotion actions. With this same focus, though undertaken in the municipalities of Belo Horizonte-MG-Brazil and Contagem-MG-Brazil, the actions were assessed in groups developed by health professionals of the Health Units ${ }^{25}$.

The educational practices of a GynecologicalObstetric Unit of a public hospital in Rio Grande do Sul- RS- Brazil were also assessed. These occurred during guidance groups on health promotion in pregnancy and the puerperium. Forty-nine guidance sessions were held in which 54 pregnant women, 34 companions and 136 puerperae, as well as professionals of the health team and academic nursing personnel, took part ${ }^{14}$.

However, other studies bet on conversation groups as efficient instruments for health promotion, emphasizing that these groups permitted the participants to have their say as the subjects of the discourse. Thus narrative investigation arises as characteristic of the cooperative process in which the participants play the role, which they themselves live, and relate their stories, all at one and the same time 22 .

Within this context, the above-mentioned authors concluded, as the result of their investigation, that the story-teller workshops were efficacious, thus pointing the way forward to change, re-signification and resistance, evidence which corroborates that of another study that emphasizes that group activities create the opportunity for the clarification of doubts and health education on the health-disease process, thus becoming an instrument for health promotion and provider of autonomy with regard to self-care ${ }^{14}$.

Further corroborating those same authors, research reveals the effectiveness of educational groups as a strategy capable of re-orienting the health care of the elderly within the perspective of health promotion in Basic Care ${ }^{26}$.

The attempt to include educational games has also been evidenced ${ }^{30}$. Within this context, in considering the importance of the various ways of implementing actions so that they attend to the principles of health promotion, the attempt to use educational games contrasts with traditional pedagogy seeing that it allows the pupil to be the active agent of his own knowledge ${ }^{27}$.

It is, however, necessary to understand that, depending on how the educational actions are used they may become simply a means of transmission of information, thus betraying their original objective - that of creating conditions such as would produce a transformation of behavior, also being practices that would result in cure, encouraging the medicalization of society in the search for responses to disease.

Within this context, some results of the studies under analysis stand out as pointing to educational actions consistent with health promotion at the same time as traditional actions, undertaken simply for the transmission of information, are also evidenced.

It is clear that the nurses hold groups with existing programmatic clippings in force in the practice of traditional public health, reduced to collective information on diseases and their treatment, becoming consolidated as an assistentialist strategy while the dimension of empowerment for the exercise of citizenship is reduced ${ }^{15}$.

When the practice of groups as health promotion actions within the family health strategy was investigated, the use of traditional educational methodologies, such as talks for the transmission of information, became clear, as also did the slight participation of the members of the group because these do not often attend to their needs seeing that they are organized in accordance with the interest of the professional concerned ${ }^{25}$.

Within the prospect of health promotion contributing to a possible change in behavior, the reflective, critical and creative potential of the group may be presented as evidence, thus constituting an important intervention strategy for the nurse who works with a view to the emancipation of their clients ${ }^{24}$.

The authors conclude, further, that group activities give the opportunity for the clarification of doubts and health education regarding the healthdisease process, thus becoming a tool for health promotion and provider of autonomy in terms of self-care ${ }^{14}$. They should thus be accessible so as to facilitate the health promotion which perfects individuals' knowledge and awareness ${ }^{23}$.

Also noteworthy are some studies which emphasize decision-making in health, made possible by the undertaking of educational actions within the perspective of health promotion ${ }^{20}$.

Health education groups are thus seen as providing an atmosphere which promotes individual and collective empowerment as they give value to the participation of the population in general, strengthening the social control of the services as well as making educational work more adequate. They, therefore, promote personal social development by disseminating information and stimulating dialog. It should be emphasized that enabling people to learn during their lives is a crucial element in the various phases of their lives as it enables them to face up to and take decisions as regards the maintenance of their health ${ }^{28}$.

It should be emphasized that educational actions constitute the range of situations which characterize the delivery of services to the population and that the involvement of all the actors is an unequalled condition for the full exercise of public health ${ }^{29}$. Thus the systematic action on the part of government and associated organizations is necessary to reach the population, as for example, 
women and the new-born with a view to effective attendance $^{30}$. It is therefore understood that actions consistent with the presuppositions of health promotion are of great importance for the achievement of quality of life and equity in health; the implementation of these actions being a challenge in view of the predominance of curative and individualistic practices.

Finally, health education, understood as an instrument to make health promotion actions viable, has been gaining ground since the Ottawa Conference, though in Brazil it has advanced on the

\section{REFERENCES}

1. Rocha V, Schall VT, Lemos ES. A contribuição de um museu de ciências na formação de concepções sobre saúde de jovens visitantes. Interface - Comunic., Saúde, Educ. 2010; 14: 183-96. Disponível em: <http:// www.scielo.br/pdf/icse/v14n32/15.pdf >. Acesso em: 24 nov. 2011. doi: 10.1590/S141432832010000100015.

2. Alves VS. Um modelo de educação em saúde para o Programa Saúde da Família: pela integralidade da atenção e reorientação do modelo assistencial. Interface (Botucatu), 2005: 9.

3. Maciel MED. Educação em saúde: conceitos e propósitos. Cogitare Enferm.2009; 140: 773-6.

4. Carvalho SR. As contradições da promoção à saúde em relação à produção de sujeitos e a mudança social. Ciênc. saúde coletiva. 2004; 9: 669-678.

5. Buss PM. Promoção da saúde e qualidade de vida. Ciênc e Saúde Coletiva. 2000, 5: 163-77-5.

6. Brasil. Ministério da Saúde. Projeto promoção de saúde: Carta de Ottawa. Secretaria de Política de Saúde. Brasília, DF, 2001.

7. Bordenave JD, Pereira AM. Estratégias ensinoaprendizagem. 28.ed. Petrópolis: Vozes, 2007.

8. Freire P. Educação e mudanças. 30.ed. Rio de Janeiro: Paz e Terra, 2007.

9. Pontes APM, Cesso RGD, Oliveira DC, Gomes AMT. Facilidades de acesso reveladas pelos usuários do Sistema Único de Saúde. Rev. bras. Enferm. 2010; 63.

10. Ministério da Saúde (BR). Saúde dentro de casa: Programa de Saúde da Família. Fundação Nacional da Saúde. Brasília, DF, 1994.

11. Ministério da Saúde (BR). Política Nacional da Promoção da Saúde. Secretaria de Vigilância a Saúde. Secretaria da Atenção Básica. Brasília, DF: 2006.

12. Tesser CD, Garcia AV,Argenta CE, Vendrusculo C. Concepções de promoção da saúde que permeiam o ideário de equipes da estratégia saúde da família da grande Florianópolis. R. Saúde Públ. Santa Cat. 2010; 3.

13. Roecker S, Marcon SS. Educação em saúde. Relatos das vivências de enfermeiros com a Estratégia da Saúde Familiar. Invest. educ. enferm nov. 2011; 29: 381-90.

14. Diaz CMG, Hoffmann IC, Costenaro RGS, Soares RS, Silva BR, Lavall BC. Vivências educati- basis of the process of health reform, more precisely with the change of the public assistance model which has been making new practices in the sector possible and affirming the impossibility of separating clinical work and health promotion.

Researchers are concerned as regards the organization of these actions as to whether they are consistent with health promotion. The challenge for health professionals is that they should work within the health promotion perspective, seeing that they are involved in a model which seeks the empowerment of the users.

vas da equipe de saúde em Unidade gineco-obstétrica. Cogitare Enferm. 2010; 15: 364-7.

15. Silva MAM, Pinheiro AKB, Souza ÂM A, Moreira ACA. Promoção da saúde em ambientes hospitalares. Rev. bras. enferm. [online]. 2011; 64: 596-599. Disponível em: http:// ww w. scielo.br/scielo.php? script =sci_serial\&pid $=0034-7167 \&$ Ing $=e n \& n r m=i s o$.

16. Paim JS. Desafios para Saúde Coletiva no século XXI. Salvador-Ba: EDUFBA, 2009:90

17. Girondi JBR, Nothaf SC dos S, Mallmann FMB. A metodologia problematizadora utilizada pelo enfermeiro na educação sexual de adolescentes. Cogitare Enferm. 2006; 11:161-5.

18. Machado MFAS, Vieira, NFC. Educação em saúde: o olhar da equipe de saúde da família e a participação do usuário. Rev. Latino-Am. Enfermagem.2009:17.

19. Rossman $\mathrm{CL}$, Ayolla AB. Promover experiências de amamentação. individualizados. MCN Am J Matern Child Nurs. 2012; 37:193-199.

20. Maria Truesdale-Kennedy ${ }^{1}$, Laurence Taggart ${ }^{2}$, Sonja McIlfatrick ${ }^{3}$. Breast cancer knowledge among women with intellectual disabilities and their experiences of receiving breast mammography. Journal of Advanced Nursing. 2011. 67: 1294-1304.

21. Moretti AC. et al . Práticas corporais/atividade física e políticas públicas de promoção da saúde. Saúde soc.2009;18.

22. Meneghel SN, Farina O, Silva LB da, Walter L, Brito SG, Selli L, Schneider V. Histórias de Dor e de Vida: oficinas de contadores de histórias. Saúde Soc. 2008; 17: 220-228

23. Leitåo A, Souza C, Silva E, Barbosa E, Santos E, Ramos E, Lima G, Silveira L, Ramos L, Silva $M$, Nascimento $S$. Prevençåo de hipertensåo arterial em crianças de 3 a 12 anos na comunidade de Joåo Paulo II. Divulg. saúde debate 2004 dez; 3: 66-68.

24. Rêgo MAB. Educação para saúde como estratégia de intervenção de enfermagem junto às pessoas portadoras de diabetes. Rev Eletrônica Enferm [periódico na internet]. 2008 [acesso em 28 janeiro 2013]; 10(1):263-5. Disponível em: http://www.fen.ufg.br/revista/v10/ n1/v10n1a30.htm

25. Horta NC, Sena RR, Silva MEO, Tavares TS, Caldeira IM. A prática de grupos como ação de promoção da saúde na estratégia saúde da família. Rev. APS jul/set. 2009; 12: 293-301.

26. Firmino R, Patrício J, Rodrigues L, Cruz P, Vasconcelos AC. Educação popular e promoção da 
saúde do idoso: reflexões a partir de uma experiência de extensão universitária com grupos de idosos em João Pessoa-PB. Rev. APS out.-dez. 2010; 13: 523-30.

27. Ramfelt, Lützén K. Patients with cancer: their approaches to participation in treatment plan decisions. Rev. Nurs Ethics Mar. 2005, 12: 143-55.

28. Motta MGC, Ribeiro Nair RR, Pedro ENR, CoeIho DF. Adolescent mother experience and her family. Acta sci., Health sci. 2004; 26: 249-256.

29. Atrash HK, Carpentier R. The evolving role of public health in the delivery of health care. Journal of Human Growth and Development, 2012; 22(3): 396-399.

30. Atrash HK. Childhood mortality: still a global priority. Journal of Human Growth and Development, 2013; 23(3): 257-260.

31. Torres HC, Hortale VA, Schall V. A experiência de jogos em grupos operativos $\mathrm{Na}$ educação em saúde para diabético. Cad. Saúde Pública, Rio de Janeiro. 2003; 19: 1039-1047.

32. Pereira J M, Helene L M F. Reeducação alimentar e um grupo de pessoas com sobrepeso e Obesidade: relato de experiência. Revista Espaço para a Saúde, Londrina. 2006; 7: 32-38

33. Moncunill IA, Hilas,E, Calamari SE, Molina G, Cornejo LS. Estrategia mediadora para la promoción de salud bucal en niños y adolescentes con síndrome de Down/ No disponible. Rev. Síndr. Down. 2007; 24: 62-67.

34. Penteado RZ, Camargo AMD, Rodrigues CF, Silva CR, Ross D, Silva JTC. et al. Vivência de voz com crianças:análise do processo educativo em saúde vocal. Distúrb Comun, São Paulo. 2007; 19: 237-246.
35. Costa GD, Cotta RMM, Ferreira MLSM, Reis JR, Franceschini SCC. Saúde da família: desafios no processo de reorientação do modelo assistencial. Rev Bras Enferm Brasília. 2009; 62: 113-8

36. Barbosa LA, Sampaio ALA, Melo ALA, Macedo APN, Machado MFAS. A educação em saúde como instrumento na Prevenção de parasitoses. RBPS, Fortaleza. 2009; 22: 272-278.

37. Carneiro DGB, Magalhães KLO, Vasconcelos ACCP, Cruz PJSC. O agente comunitário de saúde e a promoção da segurança alimentar e nutricional na estratégia saúde da família: reflexões a partir de uma experiência educativa. Rev. APS;13(4), out.-dez. 2010.

38. Combinato DS, Dalla Vecchia M., Lopes EG, Manoel RA, Marino HD, Oliveira AC. et al. "Grupos de conversa": saúde da pessoa Idosa na estratégia saúde da família. Psicologia \& Sociedade. 2010; 22: 558-568.

39. Baldissera VDA, Bueno SMV. O lazer e a saúde mental das pessoas hipertensas: convergência na educação para a saúde. Rev Esc Enferm USP. 2012 ; 46: 380-7.

40. Baldissera VD, Bueno SM, Hoga LA. Improvement of older women's sexuality through emancipatory education. Health Care Women Int. 2012;33: 956-72.

41. Rossman CL, Ayoola AB. MCN. Promoting individualized breastfeeding experiences. Am J Matern Child Nurs. 2012;37: 193-9.

42. Roecker S, Marcon SS. Educação em saúde. Relatos das vivências de enfermeiros com a Estratégia da Saúde Familiar. Invest. educ. enferm nov. 2011; 29: 381-90.

\section{RESUMO}

Descrever as práticas educativas realizadas por profissionais de saúde tomando como referência o modelo da promoção da saúde. Trata-se de revisão sistemática realizada a partir da busca de artigos nas bases de dados: Medline, Lilacs e Scielo, considerando o período de 2003 a 2013. A busca foi realizada por meio do método integrado, utilizando-se os termos: promoção da saúde, educação em saúde e vivências. Diante os resultados foi possível evidenciar a importância da realização de vivências de educação em saúde em diferentes contextos: atenção primária, hospitalar e escolar, com diversos temas e metodologias adotadas. No entanto, embora essas vivências tenham sido implementadas, em sua maioria, com vista à promoção da saúde, destacando elementos como autonomia, empoderamento e tomada de decisão, perceberam-se ainda ações de educação em saúde normativas, o que fragilizam o processo de empoderamento dos indivíduos.

Palavras-chave: promoção da saúde, educação em saúde, vivências 